\title{
IMPACT OF CLIMATE CHANGE ON THE POTENTIAL DISTRIBUTION OF NATIVE AND INVASIVE GRASSES IN THE CERRADO
}

\author{
Paula Alves Oliveira ${ }^{*}$, Cristiane Coelho de Moura $^{2}$, Lidia Gabriella Santos ${ }^{3}$, Israel Marinho Pereira ${ }^{4}$, Marcelo \\ Leandro Bueno 5 , Evandro Luiz Mendonça Machado ${ }^{6}$
}

\footnotetext{
1*Universidade Federal dos Vales do Jequitinhonha e Mucuri, Programa de Pós Graduação em Ciência Florestal, Diamantina, Minas Gerais, Brasil - oliveiraalvespaula@gmail.com (*AUTOR PARA CORRESPONDÊNCIA)

${ }^{2}$ Universidade Federal dos Vales do Jequitinhonha e Mucuri, Programa de Pós Graduação em Ciência Florestal, Diamantina, Minas Gerais, Brasil-kinhadtna@gmail.com

${ }^{3}$ Universidade Federal dos Vales do Jequitinhonha e Mucuri, Programa de Pós Graduação em Ciência Florestal, Diamantina, Minas Gerais, Brasil - lidiagabriellasantos@gmail.com

${ }^{4}$ Universidade Federal dos Vales do Jequitinhonha e Mucuri, Programa de Pós Graduação em Ciência Florestal, Diamantina, Minas Gerais, Brasil - imarinhopereira@gmail.com

${ }^{5}$ Universidade Estadual do Mato Grosso do Sul, Departamento de Biologia Vegetal, Mundo Novo, Mato Grosso do Sul, Brasil buenotanica@gmail.com

${ }^{6}$ Universidade Federal dos Vales do Jequitinhonha e Mucuri, Programa de Pós Graduação em Ciência Florestal, Diamantina, Minas Gerais, Brasil - machadoelm@gmail.com
}

Recebido para publicação: 21/01/2019 - Aceito para publicação: 12/07/2019

\begin{abstract}
Resumo
Impactos das mudanças climáticas na distribuição potencial de gramínea nativa e gramínea invasora do Cerrado. A invasão biológica, principalmente por gramíneas africanas, é uma das principais ameaças à biodiversidade do Cerrado. Assim, objetivou-se com este trabalho, elucidar os padrões de distribuição da gramínea exótica Melinis minutiflora e da gramínea nativa Trichanthecium cyanescens, a fim de verificar as áreas de potencial ocorrência destas espécies e com isto, inferir se elas terão sua potencial distribuição afetada pelas mudanças climáticas. Foram utilizados dados de ocorrência das espécies, e 10 variáveis climáticas não correlacionadas referentes às previsões para o período atual e previsões futuras (2050 e 2070) para a análise da modelagem. Os modelos indicaram a existência de adequabilidade ambiental, sendo observados AUCs acima de 0,8 (bom) para M. minutiflora e acima de 0,9 (excelente) para $T$. cyanescens. Conclui-se que, as mudanças climáticas poderão acarretar em impactos negativos sobre a distribuição geográfica dessas espécies, diminuindo a área de adequabilidade ambiental das mesmas. Além disso, as espécies estudadas possuem áreas de potencial distribuição semelhantes e com elevada sobreposição, o que pode tornar M. minutiflora uma ameaça à conservação da $T$. cyanences, devido ao potencial invasor de $M$. minutiflora.
\end{abstract}

Palavras-chave: invasão biológica, Trichanthecium cyanescens, modelagem, competição, Melinis minutiflora.

\begin{abstract}
Biological invasion, mainly by African grasses, is one of the main threats to the Cerrado's biodiversity. The objective of this study was to elucidate the distribution patterns of the exotic grass Melinis minutiflora and the native grass Trichanthecium cyanescens, in order to verify the areas of potential occurrence of these species and, thus, to infer if their potential distribution will be affected by climate changes. Species occurrence data and ten uncorrelated climatic variables referring to the forecasts for the current period and future forecasts (2050 and 2070) were used for the analysis of the modeling. The models indicated the existence of environmental suitability, with AUCs above 0.8 (good) being observed in M. minutiflora and above 0.9 (excellent) in $T$. cyanescens. It is concluded that climate change may have negative impacts on the geographic distribution of these species, reducing the area of environmental suitability for them. In addition, the species studied have similar areas of potential distribution and regularly overlap, which can make M. minutiflora a threat to the conservation of $T$. cyanences, due to the invasion potential of the first.

Keywords: biological invasion, Trichanthecium cyanescens, modeling, competition, Melinis minutiflora.
\end{abstract}

\section{INTRODUCTION}

The introduction of species in environments outside their natural range is a technique that can cause changes in ecosystems. Some of these exotic species can reach be considered invasive when, once established, their reproduction and dispersion rate rapidly increase, which may cost the replacement of native species (MAGALHÃES; SILVA-FORSBERG, 2016).

FLORESTA, Curitiba, PR, v. 50, n. 3, p. 1555 - 1564, jul/set 2020

Olveira, P. A. et.al.

ISSN eletrônico 1982-4688

DOI: $10.5380 /$ rf.v50 i3. 64389 
Currently, biological invasion, mainly by African grasses, is one of the main threats to biodiversity for the largest neotropical savanna, the Cerrado (BARBOSA et al., 2016). In the conservation units of the Cerrado, 56 exotic species with this potential, with different forms of life, have been cataloged (SAMPAIO; SCHMIDT, 2013). Among these, the exotic grass Melinis minutiflora P. Beauv. ("molasses grass") is considered the main invasive plant in this domain (MARTINS et al., 2011). Despite the high levels of biodiversity and the importance of its ecosystem services, the vegetation of the Cerrado is being rapidly destroyed (FERNANDES et al., 2016). Between 2002 and 2011, for example, deforestation rates in the Cerrado were 2.5 times higher than in the Amazon (STRASSBURG et al., 2017).

Melinis minutiflora is an extremely aggressive grass that has large production of viable seeds, rapid growth and great biomass productivity (MARTINS et al., 2011). In addition to the high accumulation of combustible material, M. minutiflora has compounds and oil resins that favor fires of greater intensity in the Cerrado countryside (BARBOSA et al., 2016). Frequent and more intense fires lead to the predominance of $M$. minutiflora to the detriment of native monocots and dicots, which are less resistant to fire (ROSSI et al., 2014). The presence of $M$. minutiflora in the community, especially when in association with other exotic grasses such as Urochloa decumbens (Stapf) R.D. Webster, can lead to the replacement of grasses (Poaceae and Cyperaceae) native to the Cerrado (ROSSI et al., 2014). According to Damasceno et al. (2018), native grasses belong to the functional group most negatively affected by the presence of invasive grasses such as M. minutiflora and Urochloa brizantha (Hochst. Ex A. Rich.) RD Webster.

Among angiosperms of the Cerrado, grasses (Poaceae) occupy the fourth position of importance (FILGUEIRAS, 2012), which makes M. minutiflora an even greater threat to the conservation of this domain. By colonizing the environment, this invasive species can prevent the establishment of new individuals, in addition to causing the mortality of species already present in the area (SILVA et al., 2013).

However, there are still doubts as to whether invasive species actually cause the decline of native species, or whether the changes in environmental conditions caused by these species lead to this decline (GUREVITCH; PADILLA, 2004). Furthermore, will native and exotic species respond in the same way to climate change?

Thus, the objective of this study is:

a) to evaluate the distribution patterns of the exotic grass Melinis minutiflora and the native grass Trichanthecium cyanescens (Nees ex Trin.) Zuloaga \& Morrone in the Cerrado, in order to verify if the areas of potential occurrence of these species overlap;

b) to infer how climate change will affect the potential distribution of these species in the Cerrado.

\section{MATERIALS AND METHODS}

The Cerrado domain was selected for modeling because it is an internationally recognized biodiversity hotspot, as it presents a significant number of endemic species (MYERS et al., 2000). The species studied were grasses, M. minutiflora exotic species and $T$. cyanescens native species, both with $\mathrm{C} 4$ photosynthetic metabolism. M. minutiflora was selected due to its invasive potential, being therefore considered a threat to the Cerrado's biodiversity (MARTINS et al., 2011), while T. cyanescens was selected because it is a frequent and abundant native species in the Cerrado.

Species occurrence data were imported from the SpeciesLink database (http://splink.cria.org.br) and from the Global Biodiversity Information Facility (GBIF) database (https://www.gbif.org). During data processing, occurrence points that showed inconsistency in the information (incomplete location, repeated or close coordinates and doubtful occurrence points) and that were not within the defined area of the Cerrado and Africa (exclusively for the invading grass) were removed from the analyses. After compiling the data, 51 points of occurrence were selected for the species T. cyanescens and 110 for M. minutiflora and 433 points for M. minutiflora (Figure 1).

FLORESTA, Curitiba, PR, v. 50, n. 3, p. 1555 - 1564, jul/set 2020.

Olveira, P. A. et.al.

ISSN eletrônico 1982-4688

DOI: 10.5380/rf.v50 i3. 64389 


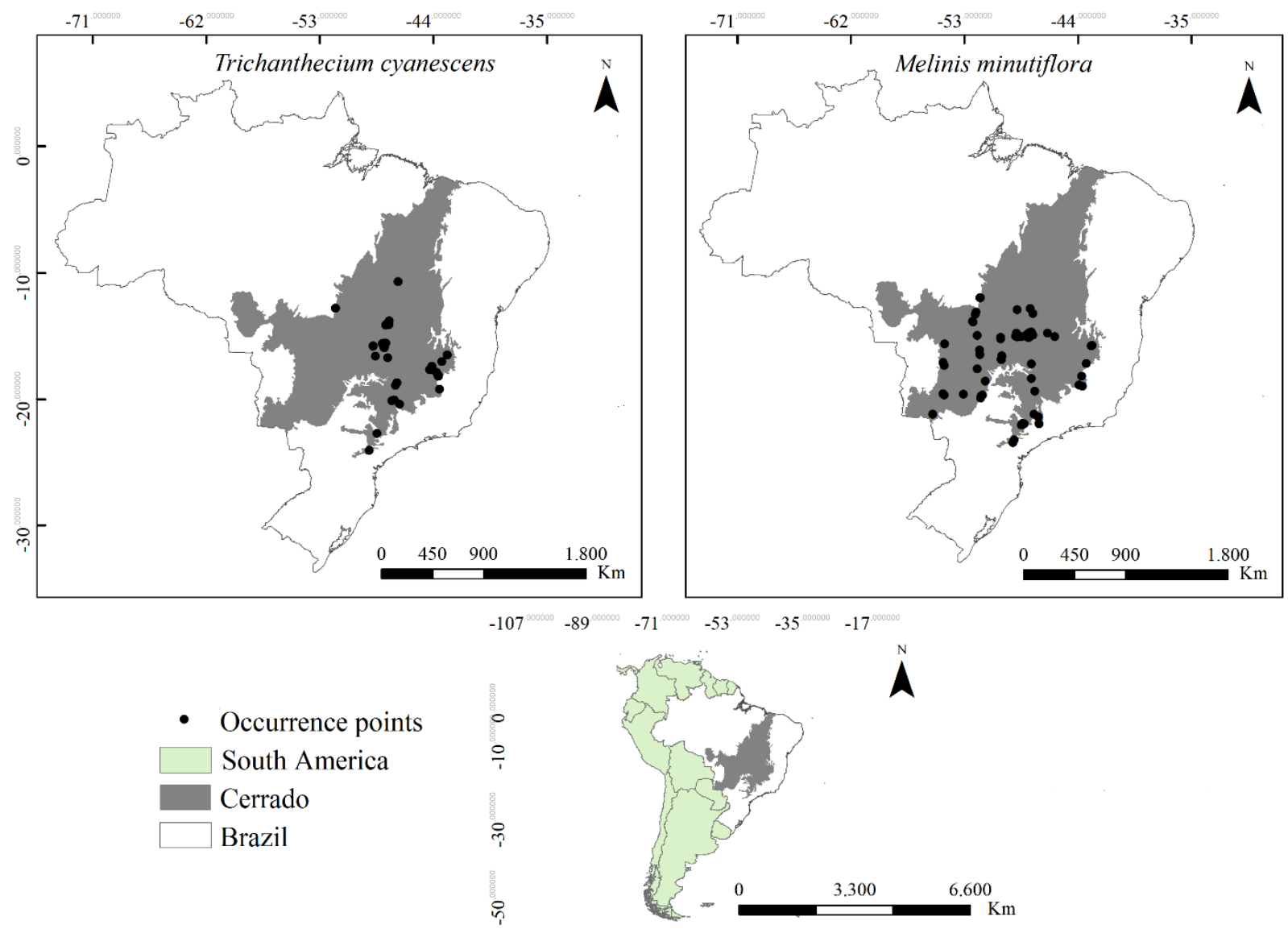

Figure 1. Points of occurrence of $T$. cyanescens and $M$. minutiflora extracted from the database available on the SpeciesLink (http://splink.cria.org.br).

Figura 1. Pontos de ocorrência de T. cyanescens e M. minutiflora extraídos do banco de dados disponíveis no site do SpeciesLink (http://splink.cria.org.br).

The bioclimatic variables, used in the analysis of the modeling, were extracted from the WorldClim database (http://www.worldclim.org/), being composed by climatic data referring to forecasts for the current and future period, with resolution of approximately $1 \mathrm{~km}$ (30 arc seconds). These are derived from the monthly records of temperature and precipitation used in modeling species distribution, and represent annual trends, seasonality and extreme or limiting environmental factors.

In order to produce models to infer grass distribution, projections of occurrence suitability were produced for the present (1960-1990) using the Community Climate System Model (CCSM4) (GENT et al., 2011), and for the future using the optimistic (rcp 2.6) and pessimistic (rcp 8.5) CCSM4 of the years 2050 and 2070, both based on the climate simulations with global climate models (GCMs) improved in the Intercompared Project of the Coupled Model Phase 5 (TAYLOR et al., 2012 ), withing the study area, that is, the Cerrado domain.

In order to select the most suitable bioclimatic variables for the study, a Pearson Correlation analysis was performed in ArcGis 10.1 as the selection criterion, eliminating the bioclimatic variables that had multicollinearity $r \geq 0$.9. The elimination of correlated variables is an extremely important step in modeling: their presence causes multicollinearity, which can lead to a misinterpretation of the results (GIANNINI et al., 2012).

The ten variables selected were: mean annual temperature (bio 01), mean daytime temperature variation (bio 02), isothermality (bio 03), temperature seasonality (bio 04), annual thermal amplitude (bio 07), annual precipitation (bio 12), precipitation of the wettest month (bio 13), precipitation of the driest month (bio 14), precipitation of the warmest quarter (bio 18) and precipitation of the coldest quarter (bio 19).

The modeling was performed using MAXENT 3.4, which is based on the principle of maximum entropy, in which the estimated distribution must agree with everything that is known, but must avoid placing any unfounded restrictions (PHILLIPS, 2017). This program uses as input a set of environmental variables such as temperature, precipitation, among others, and a set of georeferenced occurrence sites in order to produce a distribution model of the analyzed species. For the species M. minutiflora, environmental variables and points of

FLORESTA, Curitiba, PR, v. 50, n. 3, p. 1555 - 1564, jul/set 2020.

Olveira, P. A. et.al.

ISSN eletrônico 1982-4688

DOI: $10.5380 /$ rf.v50 i3. 64389 
occurrence of the Brazilian Cerrado domain and Africa, where this species originated, were used. As for $T$. cyanescens, the data used were only from the area of interest of the study and place of origin of the species, the Cerrado.

In the Maxent software, 5,000 interactions were used with ten repetitions of the subsample type. The data were divided into training $-75 \%$ of the occurrences- and the remaining $25 \%$ were used for validation to obtain a more robust distribution possibility surface.

To assess the predictions made, the area under the ROC curve (Receiver Operating Characteristic Curve), called AUC, was calculated, since this is a test widely used for this purpose (GIANNINI et al., 2012). These values are provided by Maxent himself. The value for AUC can be between 0.5 and 1 . If the model obtains an AUC value above 0.75 , it means that it is potentially useful; the closer it is to 1 , it is considered more efficient (PHILLIPS, 2017).

With the Maxent program, it was possible to estimate the most important bioclimatic variables in the model using the Jackknife test, which has been used to estimate the variance and the trend of any estimator. The Jackknife test is a method of randomization, in which at each stage a variable (bioclimatic) is removed from the data set and the statistics are then recalculated (GOTELLI; ELLISON, 2011). This process is performed according to the number of variables used in the analysis.

To check the existence or not of overlapping niches for the analyzed species, the tool ENMTools, version 1.4.4 (WARREN et al., 2010), was used. It was then possible to determine the similarity of the species distributions, obtaining an index that varies from 0 (when the models of the areas with environmental suitability do not overlap) to 1 (identical niche models, total overlap of the niches).

Maps of species distribution have been prepared today and, in the future, containing geospatial data in the form of vector of conservation units (CU) present in the Cerrado domain. The shapefile was obtained from the website <http://observatorio.wwf.org.br/mapa/.> . All modeling steps were performed using ArcGIS, version 10.1.

\section{RESULTS}

For M. minutiflora and T. cyanescens, AUC values above 0.8 and 0.9 were found with standard deviations below 0.03 and 0.07 , respectively, in all studied periods (Table 1).

Table 1. Values of the areas under the curve AUC (Area Under Curve) and their respective standard deviations, referring to the distribution modeling of M. minutiflora and T. cyanescens species located in the Cerrado.

Tabela 1. Valores das áreas sob a curva AUC (Area Under Curve) e seus respectivos desvios-padrão, referente à modelagem de distribuição das espécies M. minutiflora e T. cyanescens localizadas no Cerrado.

\begin{tabular}{|c|c|c|c|c|c|}
\hline \multirow{3}{*}{ Model } & \multirow{3}{*}{ Period } & \multicolumn{4}{|c|}{ Species } \\
\hline & & \multicolumn{2}{|c|}{ Melinis minutiflora } & \multicolumn{2}{|c|}{ Trichanthecium cyanescens } \\
\hline & & AUC & Standard deviation & AUC & Standard deviation \\
\hline Current & - & 0.838 & 0.034 & 0.943 & 0.032 \\
\hline \multirow{2}{*}{ Future rep 8.5} & 2050 & 0.881 & 0.022 & 0.927 & 0.053 \\
\hline & 2070 & 0.865 & 0.032 & 0.924 & 0.074 \\
\hline \multirow{2}{*}{ Future rep 2.6} & 2050 & 0.859 & 0.023 & 0.910 & 0.034 \\
\hline & 2070 & 0.872 & 0.022 & 0.926 & 0.040 \\
\hline
\end{tabular}

The bioclimatic variable that most contributed to the modeling of the species M. minutiflora and $T$. cyanescens, in all analyzed periods, was the annual mean temperature (bio 01), followed by the bioclimatic variable mean diurnal range (bio 02) (Table 2). 
Table 2. Percentage of contribution referring to the environmental variables of greatest contribution in the development of potential distribution models of $M$. minutiflora and $T$. cyanescens located in the Cerrado.

Tabela 2. Percentual de contribuição referente às variáveis ambientais de maior contribuição no desenvolvimento dos modelos de distribuição potencial da M. minutiflora e T. cyanescens localizadas no Cerrado.

\begin{tabular}{|c|c|c|c|c|c|c|}
\hline \multirow{2}{*}{$\begin{array}{l}\text { Species } \\
\text { Period }\end{array}$} & \multicolumn{3}{|c|}{ Trichanthecium cyanescens } & \multicolumn{3}{|c|}{ Melinis minutiflora } \\
\hline & Variable & $\begin{array}{c}\text { Contribution } \\
(\%)\end{array}$ & $\begin{array}{c}\text { Importance } \\
\text { of } \\
\text { permutation } \\
\end{array}$ & Variable & $\begin{array}{c}\text { Contribution } \\
(\%)\end{array}$ & $\begin{array}{c}\text { Importance } \\
\text { of } \\
\text { permutation }\end{array}$ \\
\hline \multirow{3}{*}{ Current } & bio 01 & 62.4 & 81 & bio 01 & 40.2 & 12.7 \\
\hline & bio 02 & 17.5 & 0.2 & bio 02 & 20.7 & 12.4 \\
\hline & bio 14 & 5.8 & 4.3 & bio 18 & 13.2 & 8 \\
\hline \multirow{3}{*}{$\begin{array}{l}\text { Future rep } 8.5 \\
2050\end{array}$} & bio 01 & 62.6 & 58.2 & bio 01 & 37.7 & 12.6 \\
\hline & bio 02 & 15.5 & 0.2 & bio 02 & 20.7 & 7.7 \\
\hline & bio 19 & 6.4 & 28.9 & bio 18 & 13.4 & 6.3 \\
\hline \multirow{3}{*}{$\begin{array}{l}\text { Future rep } 8.5 \\
2070\end{array}$} & bio 01 & 60.2 & 55.6 & bio 01 & 36.6 & 15.9 \\
\hline & bio 02 & 16.8 & 0.6 & bio 02 & 21.6 & 7.2 \\
\hline & bio 07 & 7 & 3.1 & bio 18 & 13.1 & 9.5 \\
\hline \multirow{3}{*}{$\begin{array}{l}\text { Future rep } 2.6 \\
2050\end{array}$} & bio 01 & 58.1 & 80 & bio 01 & 37.2 & 16.2 \\
\hline & bio 02 & 24.4 & 0.8 & bio 02 & 24.6 & 16.4 \\
\hline & bio 19 & 6.2 & 7.2 & bio 18 & 14.9 & 11.1 \\
\hline \multirow{3}{*}{$\begin{array}{l}\text { Future rep } 2.6 \\
2070\end{array}$} & bio 01 & 64.1 & 77.6 & bio 01 & 37.8 & 10.7 \\
\hline & bio 02 & 17 & 0.7 & bio 02 & 22 & 12.3 \\
\hline & bio 07 & 5.9 & 4.5 & bio 18 & 12.7 & 9.3 \\
\hline
\end{tabular}

Legend: bio 01: annual mean temperature; bio 02: mean diurnal range; bio 07: temperature annual range; bio 14: precipitation of driest month; bio 18: precipitation of warmest quarter; e bio 19: precipitation of coldest quarter.

In the results of the Jackknife test in all periods analyzed for the two species, the climatic variable with the greatest return, when used in isolation, was also the annual mean temperature, which suggests that it presented the most relevant information for the species distribution. And, corroborating the results, the bioclimatic variable that decreased the return when omitted, for most scenarios, was also the annual mean temperature, indicating that this has most of the information that is not present in the other bioclimatic variables (Table 2).

The modeling for the current period showed a good fit with the geographic coordinates of the location points of T. cyanescens and M. minutiflora (Figure 2-3). 

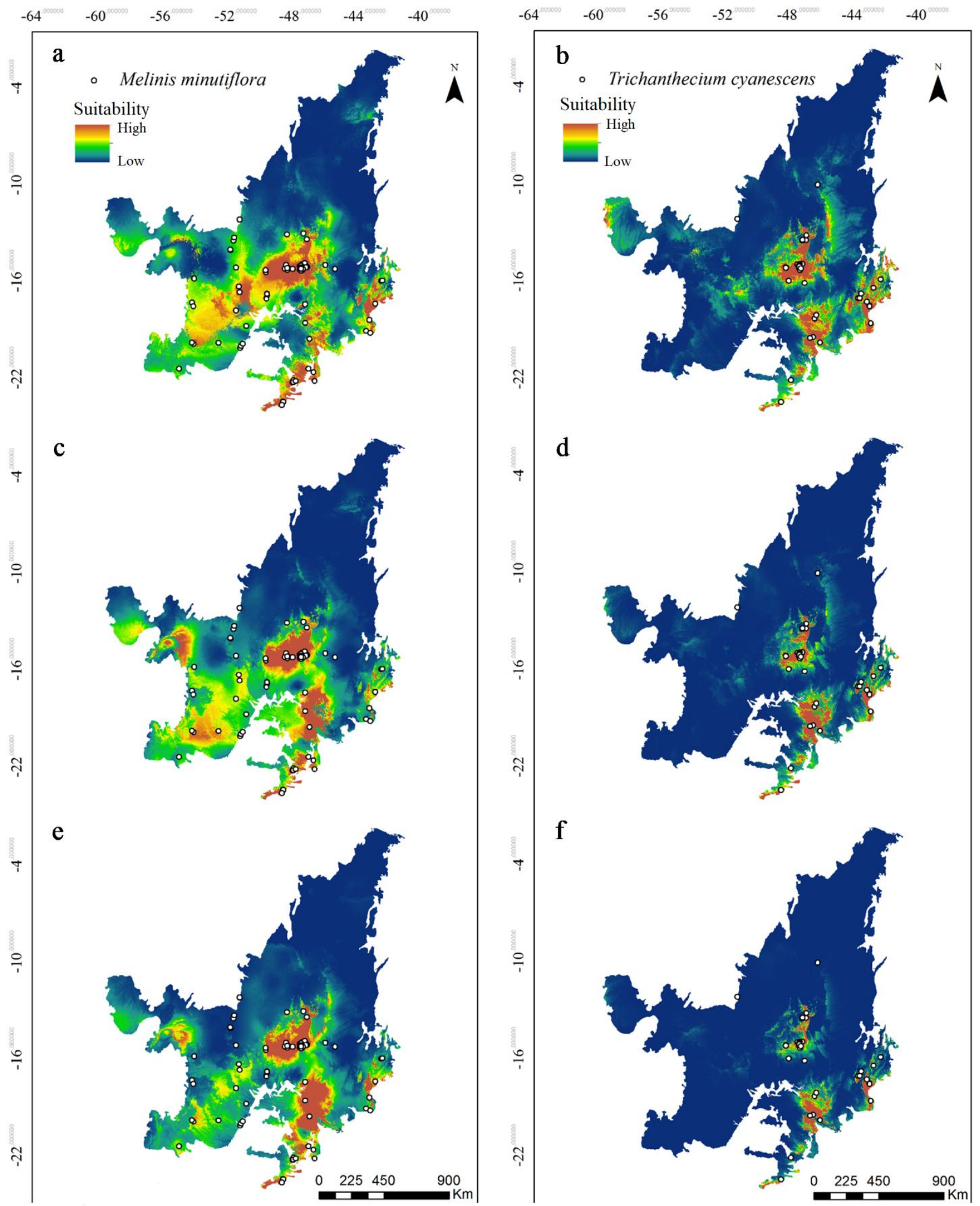

Figure 2 - Potential distribution for the current period (a-b), future of 2050 (rcp 2.6 (c-d) and rcp 8.5 (e-f)) of the species $T$. cyanescens and M. minutiflora in the Cerrado related to environmental suitability.

Figura 2 - Distribuição potencial para o período atual (a-b), futuro do ano de 2050 (rcp 2.6 (c-d) e rcp 8.5 (e-f)) das espécies $T$. cyanescens e $M$. minutiflora no Cerrado referente à adequabilidade ambiental.

FLORESTA, Curitiba, PR, v. 50, n. 3, p. 1555 - 1564, jul/set 2020.

Olveira, P. A. et.al.

ISSN eletrônico 1982-4688

DOI: 10.5380/rf.v50 i3. 64389 

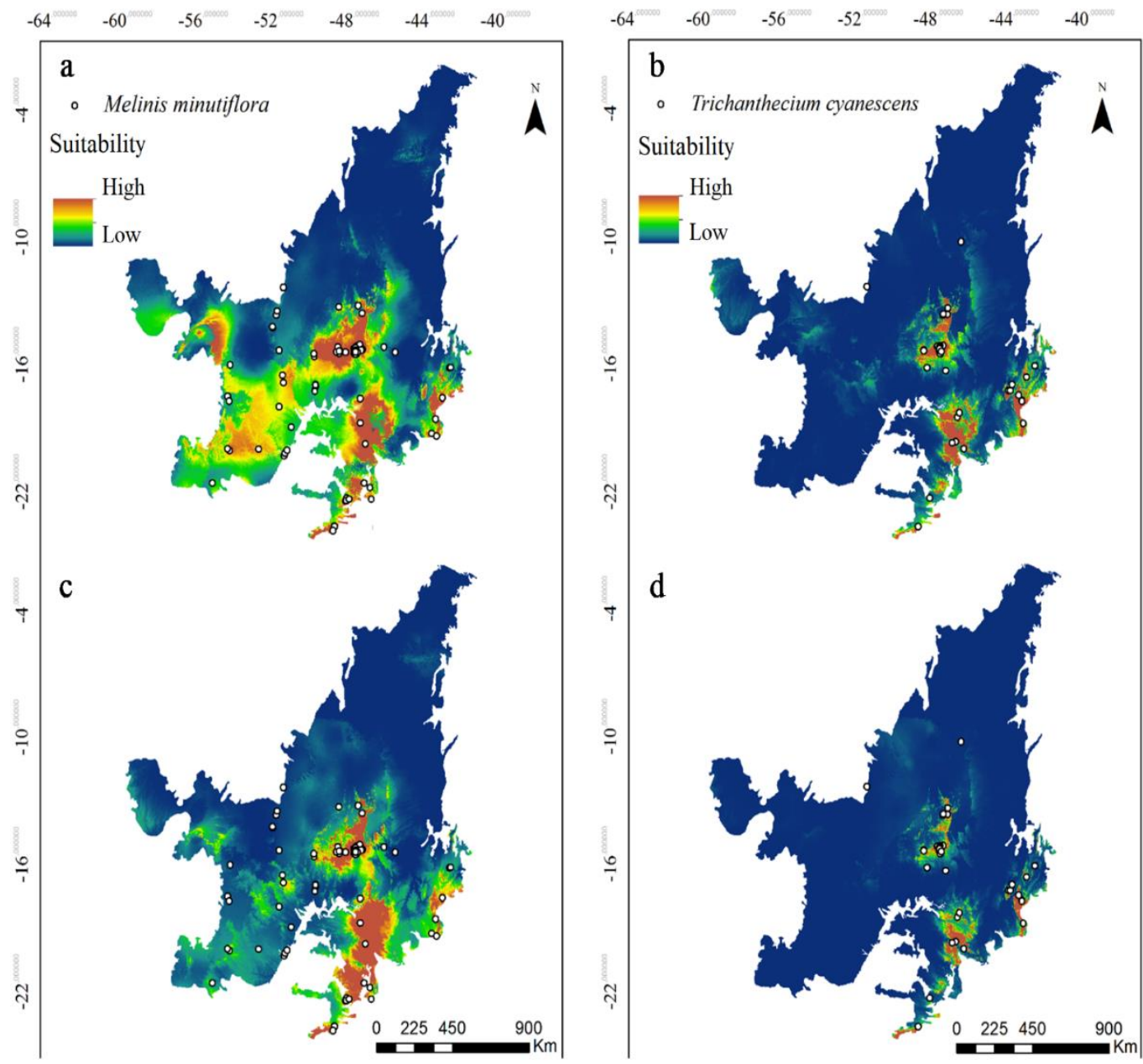

Figure 3. Potential distribution of the species T. cyanescens and M. minutiflora in the Cerrado, related to environmental suitability for the future period of 2070 (rcp 2.6 (a-b) and rcp 8.5 (c-d)).

Figura 3. Distribuição potencial para o período futuro do ano de 2070 (rcp 2.6 (a-b) e rcp 8.5 (c-d)) das espécies T. cyanescens e M. minutiflora no Cerrado referente à adequabilidade ambiental.

The two species in question have very similar niches (Table 3). In addition, to facilitate the visualization of the overlapping of the species niches, the maps of the rcp 2.6 and rcp 8.5 scenarios of the years 2050 and 2070 were added, thus composing a single environmental suitability map for each species, plotted together with the conservation units (Figure 4).

Table 3. Probability of overlapping distribution patterns of species M. minutiflora and T. cyanences, for the current and future period 2050 and 2070 in the scenarios rep 2.6 and rcp 8.5.

Tabela 3. Probabilidade de sobreposição dos modelos de distribuição das espécies M. minutiflora e T. cyanences, para o período atual e futuro 2050 e 2070 nos cenários rep 2.6 e rcp 8.5 .

\begin{tabular}{|c|c|c|c|c|c|c|c|c|c|c|}
\hline \multirow{2}{*}{ Species (period) } & \multicolumn{10}{|c|}{ Letter corresponding to species and period } \\
\hline & $\mathbf{a}$ & b & c & d & e & f & g & h & $\mathbf{i}$ & $\mathbf{j}$ \\
\hline (a) M. minutiflora (current) & 1.00 & 0.84 & 0.94 & - & 0.92 & - & 0.95 & & 0.91 & \\
\hline (b) T. cyanences (current) & - & 1.00 & - & 0.94 & - & 0.87 & - & 0.94 & - & 0.85 \\
\hline (c) M. minutiflora (2050 rcp 2.6) & - & - & 1.00 & 0.75 & 0.97 & - & 0.99 & - & 0.93 & - \\
\hline (d) T. cyanences (2050 rcp 2.6) & - & - & - & 1.00 & - & 0.96 & - & 0.99 & - & 0.94 \\
\hline (e) M. minutiflora (2050 rcp 8.5) & - & - & - & - & 1.00 & 0.74 & 0.97 & - & 0.97 & \\
\hline (f) T. cyanences (2050 $\mathrm{rcp} 8.5)$ & - & - & - & - & - & 1.00 & - & 0.97 & - & 0.98 \\
\hline (g) M. minutiflora (2070 rсp 2.6) & - & - & - & - & - & - & 1.00 & 0.78 & 0.94 & - \\
\hline (h) T. cyanences $(2070 \operatorname{rcp} 2.6)$ & - & - & - & - & - & - & - & 1.00 & - & 0.94 \\
\hline (i) M. minutiflora (2070 rсp 8.5) & - & - & - & - & - & - & - & - & 1.00 & 0.76 \\
\hline (j) T. cyanences (2070 rcp 8.5) & - & - & - & - & - & - & - & - & - & 1.00 \\
\hline
\end{tabular}

FLORESTA, Curitiba, PR, v. 50, n. 3, p. 1555 - 1564, jul/set 2020.

Olveira, P. A. et.al.

ISSN eletrônico 1982-4688

DOI: $10.5380 /$ rf.v50 i3. 64389 


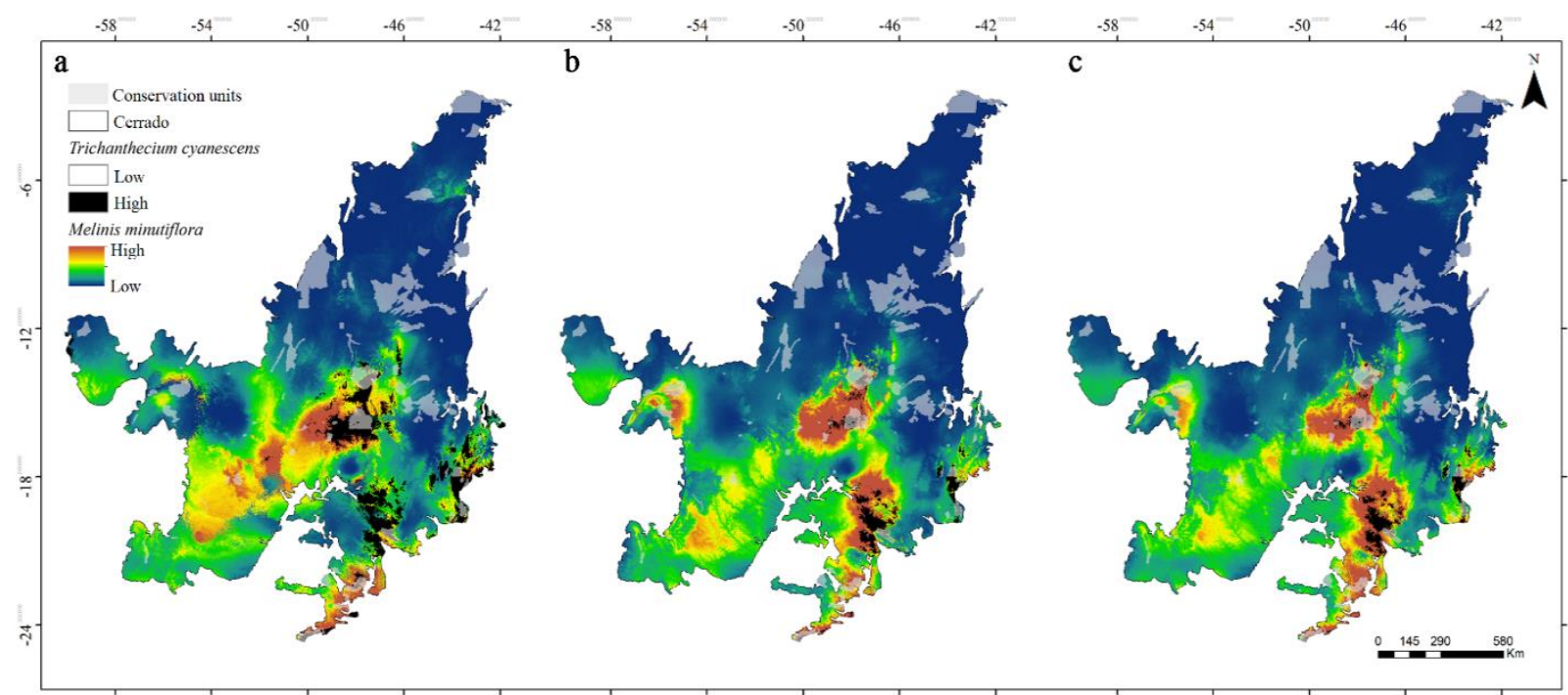

Figure 4. Modeling of the current distribution (a), in the year 2050 (b) and in the year 2017 (c) of the species $T$. cyanescens and M. minutiflora and the Conservation Units located in the Cerrado.

Figura 4. Modelagem da distribuição atual (a), no ano de 2050 (b) e no ano de 2017 (c) das espécies T. cyanescens e M. minutiflora e as Unidades de Conservação localizadas no Cerrado.

\section{DISCUSSION}

Due to the AUC value greater than 0.84, the distribution modeling indicated the existence of good to excellent environmental suitability in the geographic pattern presented by them, according to the classification of Swets (1988).

The occurrence of grasses is influenced by temperature. In a study conducted in the Venezuelan Guayana, $\mathrm{C} 4$ grasses expanded their area of occupation in warmer regions, while $\mathrm{C} 3$ grasses were restricted to colder regions, such as mountain tops (GIRALDO-CAÑAS, 2014). Therefore, it was expected that the species in this study would expand their areas with environmental suitability for future predictions, since the Intergovernmental Panel on Climate Change (IPCC) predicts an increase in temperature of up to $1.7^{\circ} \mathrm{C}$ or $4.8^{\circ} \mathrm{C}$, respectively, for the rcp 2.6 and rcp 8.5 scenarios (IPCC 2013).

However, it is worth mentioning that $M$. minutiflora (invasive grass) did not show suitability for annual mean temperature values above $26.8^{\circ} \mathrm{C}$, according to the limits extracted from species distribution models. Thus, with the increase in temperature predicted by the IPCC, many areas will exceed the maximum tolerated limit for the establishment of this species, which will probably result in the reduction of environmental suitability as observed in this study (Figures 2-3).

With the decrease of the environmental suitability of the species for the future, it can be observed in Figures 2 and 3 how many places with points of occurrence of the species today will no longer compose their niche. The calculated similarity contributed to the visualization of the reduction of the niches of each species in different periods. This reduction in the area of potential occurrence is greater for $T$. cyanescens, especially when comparing the current period with the rcp 8.5 scenario of the years 2050 and 2070, with $87 \%$ and $85 \%$ similarity, respectively, to the detriment of the $M$. minutiflora that presented similarity values in all scenarios, above $90 \%$ (Table 3). These places will probably compose the so-called drain areas, that is, areas considered unsuitable for maintaining populations, where the mortality rate exceeds the population increase (PULLIAM, 2000).

Modeling studies of geographical distribution have shown that there is a decreasing tendency of environmental suitability for many species in future projections (PUGA et al., 2016). However, experiments should be carried out to confirm whether the increase in temperature will actually negatively influence the potential distribution of the species in this study.

It can be seen that the two species studied have an area with very similar environmental suitability and frequent overlapping (Table 3), which can be an alarming result, since the species M. minutiflora is an exotic grass with high invasive potential and with a great capacity for replacing native grass vegetation (ROSSI et al., 2014). Thus, based on these results, the species $T$. cyanescens is at high risk of being eliminated from this ecosystem of interest in the study and replaced by $M$. minutiflora.

Conservation units are created with the function of safeguarding natural attributes, native biodiversity and genetic resources. It can be seen in Figure 4 that many conservation units are fulfilling their role with the

FLORESTA, Curitiba, PR, v. 50, n. 3, p. 1555 - 1564, jul/set 2020.

Olveira, P. A. et.al.

ISSN eletrônico 1982-4688

DOI: $10.5380 /$ rf.v50 i3. 64389 
native species $T$. cyanescens. However, where there is a high environmental suitability for T. cyanescens in the units, there is algo high suitability for M. minutiflora. This can be seen as a major problem for the persistence of T. cyanescens, as well as for other native species, if the inspection of anthropic activities within these units is not effective and the presence of invasive alien grass species are not eradicated in these areas.

Unfortunately, most of the conservation units are surrounded by areas with high anthropic pressure that end up favoring biological invasion. In the Serra do Rola-Moça State Park, for example, located in the metropolitan region of Belo Horizonte, one of the most important green areas in the Brazilian state of Minas Gerais, many miners used M. minutiflora in the rehabilitation of degraded areas (RIBEIRO et al., 2017) and today a large part of the park's territory is invaded by the species. Non-intentionally, non-governmental organizations (NGOs) in this region invested in fertilization for ecological restoration purposes, however, the improvement in soil fertility, especially in the case of nitrogen, favored the expansion of the invasive species to the detriment of native species, making it difficult to control and eradicate the exotic species within the conservation units. Therefore, these authors strictly recommend avoiding fertilization in the rupestrian field, the Cerrado physiognomy prevalent in the Park in question.

It is worth mentioning that the control and/or eradication of invasive species is very difficult. In the National Park of Brasilia, management initiatives for the species M. minutiflora have been carried out since 2003 (MARTINS et al., 2017). According to the authors, after ten years of study, the only way to reduce the infestation of the species was an integrated management that consisted of controlled burning (2003), punctual application of herbicide (2004) and manual removal of seedlings (every year between 2005 and 2013). Therefore, in places where there is biological invasion, measures such as monitoring and management are necessary to prevent the expansion of the invasive species. Thus, the control of invasive grasses is indispensable for the conservation and restoration of the Cerrado (DAMASCENO et al., 2018).

\section{CONCLUSION}

- The studied species have areas of similar distribution potential and frequently overlap, which can make $M$. minutiflora a threat to the conservation of $T$. cyanences.

- Climate change may have negative impacts on the geographic distribution of these species, reducing their area of environmental suitability in the future.

\section{ACKNOWLEDGMENTS}

This work was carried out with the support of the Coordination for the Improvement of Higher Education Personnel - Brazil (CAPES) - Financing Code 001.

\section{REFERENCES}

BARBOSA, E. G.; PIVELlO, V. R.; RISSI, M. N.; ZUPO, T.; FIDELIS, A. A importância da consideração de espécies invasoras no manejo integrado do fogo. Biodiversidade Brasileira, Brasília, v. 6, n. 2, p. 27 - 40, 2016.

DAMASCENO, G.; SOUZA, L.; PIVELLO, V. R.; GORGONE-BARBOSA, E.; GIROLDO, P. Z.; FIDELIS, A. Impact of invasive grasses on Cerrado under natural regeneration. Biological Invasions, v. 20, n. 12, p. 3621 $3629,2018$.

FERNANDES, G. W.; COELHO, M. S.; MACHADO, R. B.; FERREIRA, M. E.; AGUIAR, L. D. S.; DIRZO, R.; SCARIOT, A.; LOPES, C. R. Afforestation of savannas: an impending ecological disaster. Natureza \& Conservação, v. 14, n. 2, p. 146 - 151, 2016.

FILGUEIRAS, T. S. Gramíneas (Poaceae) no centro-oeste do Brasil. Heringeriana, Brasília, v. 6, n. 1, p. 47 48, 2012.

GENT, P. R.; DANABASOGLU, G.; DONNER, L. J.; HOLLAND, M. M.; HUNKE, E. C.; JAYNE, S. R.; LAWRENCE, D. M.; NEALE, R. B.; RASCH, P. J.; VERTENSTEIN, M.; WORLEY, P. H.; YANG, Z.; ZHANG, M. The community climate system model version 4. Journal of Climate, v. 24, n. 19, p. 4973 - 4991 , 2011.

GIANNINI, T. C.; SIQUEIRA, M. F.; ACOSTA, A. L.; BARRETO, F. C. C.; SARAIVA, A. M.; SANTOS, I. Desafios atuais da modelagem preditiva de distribuição de espécies. Rodriguésia, Rio de Janeiro, v. 63, n. 3, p. 733 - 749, 2012.

GIRALDO-CAÑAS, D. Richness and Altitudinal Distribution of C3 and C4 Grasses in the Venezuelan Guayana. Ciencia en Desarrollo, Tunja, v. 5, n. 1, p. 77 - 84, 2014.

FLORESTA, Curitiba, PR, v. 50, n. 3, p. 1555 - 1564, jul/set 2020.

Olveira, P. A. et.al.

ISSN eletrônico 1982-4688

DOI: $10.5380 /$ rf.v50 i3. 64389 
GOTELLI, N. J.; ELLISON, A. M. Princípios de Estatística em Ecologia. Porto Alegre: ARTMED, 2011, 528p.

GUREVITCH, J.; PADILLA, D. K. Are invasive species a major cause of extinctions? Trends in ecology \& evolution, Cambridge, v. 19, n. 9, p. 470 - 474, 2004.

IPCC. STOCKER, T. F.; QIN, D.; PLATTNER, G. K; TIGNOR, M.; ALLEN, S. K.; BOSCHUNG, J.; NAUELS, A.; XIA, Y.; BEX, V.; MIDGLEY, P. M. (eds.). Climate Change 2013: The Physical Science Basis. Contribution of Working Group I to the Fifth Assessment Report of the Intergovernmental Panel on Climate Change. Cambridge: Cambridge University Press, 2013, 1535p.

MAGALHÃES, L. C. S.; SILVA-FORSBERG, M. C. Espécies Exóticas Invasoras: caracterização e ameaças aos ecossistemas. Scientia Amazonia, Manaus, v. 5, n.1, 63 - 74, 2016.

MARTINS, C. R.; HAY, J. D. V.; SCALÉA, M.; MALAQUIAS, J. V. Management techniques for the control of Melinis minutiflora P. Beauv. (molasses grass): ten years of research on an invasive grass species in the Brazilian Cerrado. Acta Botanica Brasilica, Belo Horizonte, v.31, n.4, p. 546-554, 2017.

MARTINS, C. R.; HAY, J. D. V.; WALTER, B. M. T.; PROENÇA, C. E. B.; VIVALDI, L. J. Impacto da invasão e do manejo do capim-gordura (Melinis minutiflora) sobre a riqueza e biomassa da flora nativa do Cerrado sentido restrito. Revista Brasileira de Botânica, São Paulo, v. 34, n. 1, p. 73-90, 2011.

MYERS, N.; MITTERMEIER, R. A.; MITTERMEIER, C. G.; FONSECA, G. A. B. D.; KENT, J. Biodiversity hotspots for conservation priorities. Nature, v. 403, n. 6772, p. 853, 2000.

PHILLIPS, S. J. A Brief Tutorial on Maxent. Disponível em: <http://biodiversityinformatics.amnh.org/open_source/maxent/> Acesso em: 15 dez. 2017.

PUGA, N. D.; OLGUIN, J. L. L.; CORRAL, J. A. R.; EGUIARTE, D. R. G.; PAREDES, J. D. G.; GONZÁLES, S. M. Impactos del cambio climático en la distribución potencial de Morus alba L. en México. Revista Mexicana de Ciencias Agrícolas, Ciudad de México, n. 13, 2016.

PULLIAM, H. R. On the relationship between niche and distribution. Ecology letters, Oxford, v. 3, n. 4, p. 349 - 361, 2000 .

RIBEIRO, P. C.; MENENDEZ, E.; SILVA, D. L.; BONIECK, D.; RAMÍREZ-BAHENA, M. H.; RESENDESTOIANOFF, M. A.; PEIX, A.; VELÁZQUES, E.; MATEOS, P. F.; SCOTTI, M. R. Invasion of the Brazilian campo rupestre by the exotic grass Melinis minutiflora is driven by the high soil $\mathrm{N}$ availability and changes in the N cycle. Science of the Total Environment, California, v. 577, p. 202 - 211, 2017.R

ROSSI, R. D.; MARTINS, C. R.; VIANA, P. L.; RODRIGUES, E. L.; FIGUEIRA, J. E. C. Impact of invasion by molasses grass (Melinis minutiflora P. Beauv.) on native species and on fires in areas of campo-cerrado in Brazil. Acta Botanica Brasilica, Belo Horizonte, v. 28, n. 4, p. 631 - 637, 2014.

SAMPAIO, A. B.; SCHMIDT, I. B. Espécies exóticas invasoras em unidades de conservação federais do Brasil. Biodiversidade Brasileira, Brasília, v. 3, n. 2, p. 32 - 49, 2013.

SILVA, R. R.; COELHO, F. T. A.; ANJOS, M. A.; VAZ-FILHO, V. Controle do capim-gordura nas áreas de recuperação ambiental da Mineração Corumbaense Reunida (MCR), Corumbá, MS. Biodiversidade Brasileira, Brasília, v. 3, n. 2, p. 237 - 242, 2013.

STRASSBURG, B. B. N.; BROOKS, T.; FELTRAN-BARBIERI, R.; IRIBARREM, A.; CROUZEILLES, R.; LOYOLA, R.; LATAWIEC, A. E.; OLIVEIRA-FILHO, F. J. B.; SCARAMUZZA, C. A. M.; SCARANO, F. R.; SOARES-FILHO, B.; BALMFORD, A. Moment of truth for the Cerrado hotspot. Nature Ecology \& Evolution, v. 1, n. 0099, p. 1 - 3, 2017.

SWETS, J. A. Measuring the accuracy of diagnostic systems. Science, v. 240, n. 4857, p. 1285 - 1293, 1988.

TAYLOR, K. E.; STOUFFER, R. J.; MEEHL, G. A. An overview of CMIP5 and the experiment design. Bulletin of the American Meteorological Society, v. 93, n. 4, p. 485 - 498, 2012.

WARREN, D. L; GLOR, R. E.; TURELLI, M. ENMTools: a toolbox for comparative studies of environmental niche models. Ecography, v. 33, n. 3, p. 607 - 611, 2010.

FLORESTA, Curitiba, PR, v. 50, n. 3, p. 1555 - 1564, jul/set 2020

Olveira, P. A. et.al.

ISSN eletrônico 1982-4688

DOI: 10.5380/rf.v50 i3. 64389 